\title{
Increased Cytokine-Induced Cytotoxicity of Pancreatic Islet Cells from Transgenic Mice Expressing the Src-like Tyrosine Kinase GTK
}

\author{
Cecilia Annerén and Michael Welsh \\ Department of Medical Cell Biology, Uppsala University, Uppsala, Sweden \\ Contributed by D.F. Steiner. Accepted January 31, 2001
}

\begin{abstract}
Background: The loss of $\beta$ cells in type 1 diabetes may involve protein kinases because they control cell growth, differentiation, and survival. Previous studies have revealed that GTK, a Src-like protein tyrosine kinase expressed in $\beta$ cells (also named Bsk/Iyk), regulates multiple responses including growth and survival of rat insulinoma cells (RINm5F) and differentiation of neuronal PC 12 cells. In the present study, we have generated a transgenic mouse expressing a kinase active GTK mutant (GTK-Y504F) under the control of the rat insulin I promoter to establish a role of GTK in $\beta$ cells.

Materials and Methods: Control and GTK-transgenic CBA mice were used for determination of in vivo glucose tolerance and the relative insulin-positive area. Isolated islets from both groups were cultured in the absence and presence of cytokines and insulin secretion, viability and protein expression were assessed.

Results: The $\beta$-cell mass of GTK-transgenic mice was increased as a consequence of a larger pancreas and an increased relative $\beta$-cell area. Islets isolated from the transgenic animals exhibited an enhanced glucose-
\end{abstract}

induced insulin release and reduced viability in response to cytokines that could not be explained by higher levels of nitric oxide (NO) compared with control islets. Extracellular signal-regulated kinase (ERK) 1/2, p38 mitogenactivated protein kinase (MAPK), c-Jun $\mathrm{NH}_{2}$-terminal kinase (JNK), and Akt were all activated by cytokines, but GTK-transgenic islets contained higher basal levels of phosphorylated ERK1/2 and lower basal levels of phosphorylated p38 compared with the control islets. The total amount of activated MAPKs was, however, higher in the cytokine-stimulated transgenic islets compared with the control islets due to increased levels of phospho-ERK1/2. Moreover, the proline-rich tyrosine kinase (PYK) 2 (also named RAFTK/CAK $\beta /$ CADTK) levels were elevated in response to a 24-hr exposure to cytokines in control islets but not in the GTK-transgenic islets.

Conclusions: These results suggest that although GTK increases the $\beta$-cell mass, it also enhances islet cell death in response to cytokines and may thus be involved in the $\beta$-cell damage in type 1 diabetes.

\section{Introduction}

Type 1 diabetes (insulin-dependent diabetes mellitus [IDDM] ) results from a selective destruction of the insulin-producing pancreatic $\beta$ cells and a limited capacity for the remaining $\beta$ cells to regenerate in a compensatory manner. Macrophages and lymphocytes infiltrate the pancreatic islets and secrete inflammatory products, such as cytokines and free radicals that are highly toxic to the $\beta$ cells but not to the $\alpha$ cells (reviewed in [1-4]). It is presently clear that the active $\beta$-cell mass is a function of replication of preexisting $\beta$ cells, $\beta$-cell neogenesis, and $\beta$-cell survival (5), and a significant amount of research has been conducted to elucidate the signaling pathways regulating each of these.

Interleukin (IL)- $1 \beta$ has been studied extensively as a cytokine secreted by the inflammatory macrophages present in the insulitis (for a review see Mandrup-Pulsen [6]). IL- $1 \beta$ alone or in combi-

Address correspondence and reprint requests to: Cecilia Annerén, Department of Medical Cell Biology, Box 571, Biomedicum, S-751 23 Uppsala, Sweden.

Phone: +46-18-4714033; Fax: +46-18-556401;

E-mail: cecilia.anneren@medcellbiol.uu.se nation with interferon (INF)- $\gamma$ and/or tumor necrosis factor-alpha (TNF- $\alpha$ ) induces DNA fragmentation, nuclear condensation, and death of pancreatic $\beta$ cells, and these events are preceded by expression of inducible nitric oxide synthase (iNOS) and nitric oxide (NO) production (reviewed in $[1,3,4,7])$. However, some observations suggest that NO production is neither necessary nor sufficient for mediation of cytokine-induced $\beta$-cell destruction and blocking iNOs does not fully protect $\beta$ cells from cytokine-mediated inhibition of insulin release or induction of apoptosis (8). Additional mediators of cytokine-induced $\beta$-cell death may therefore be necessary, such as the Fas/FasL (9-11) and the mitogen-activated protein kinase (MAPK) cascades, which includes extracellular signal-regulated kinase (ERK-1/2), JNK (c-Jun $\mathrm{NH}_{2}$-terminal kinase), and p38 MAPK (12-14).

IL-1 has recently been shown to activate and phosphorylate the anti-apoptotic protein kinase Akt/protein kinase B in astrocytes (15) and endothelial cells (16). The p85 subunit of phosphatidylinositol 3 (PI3)-kinase was shown to interact with IL- $1 \beta$ receptor accessory, leading to the 
activation of the pllo catalytic subunit and a subsequent phosphorylation of Akt (17). Several studies have shown that IL-1-induced PI3-kinase activation causes phosphorylation and transactivation of NF $\kappa \mathrm{B}(15,17,18)$, whereas one study suggests that the effects of the PI3-kinase/Akt pathway are independent of NF $\kappa B$ (16). To date, however, it has not been investigated whether IL- $1 \beta$ induces phosphorylation of Akt in $\beta$ cells.

Protein tyrosine kinases play an important role in the regulation of growth, differentiation, and survival in all cells. In search of protein tyrosine kinases expressed in $\beta$ cells, we identified GTK, a novel Src related kinase, which was subsequently cloned from the mouse $\beta$ TC-1 cell line (19). We have in previous studies shown that Tyr-504 regulates GTK kinase activity and that mutation of this tyrosine to phenylalanine causes a 2- to 3-fold increase in GTK-kinase activity (20). RINm5F cells expressing GTK(Y504F) exhibit a decreased proliferation rate and altered hormone mRNA levels as well as a reduced cell viability in response to cytokines (20). We have also observed that wild-type GTK expressed in the rat pheochromocytoma PC12 cell line induces NGF-independent neurite outgrowth (21), suggesting a role for GTK in cell differentiation. It thus appears that GTK is involved in signal transduction pathways regulating multiple responses including growth, differentiation and survival.

In the present study, we generated a transgenic mouse expressing a kinase active GTK-mutant (GTK-Y504F) under the control of the rat insulin I promoter to establish a role of GTK for $\beta$-cell function, growth, and survival.

\section{Materials and Methods \\ Materials}

Fetal calf serum (FCS) and penicillin/streptomycin solutions were purchased from HyClone Europe Ltd (Cramlington, UK). Phenylmethylsulfonylflouride (PMSF) was from Sigma Chemical Co (St. Louis, MO, USA). Immobilon-P was from Millipore Corporation (Bedford, MA, USA), horse radish peroxidase linked donkey anti-rabbit or anti-mouse IgG, enhanced chemiluminescence (ECL) detection system; Rainbow Molecular Weight Standard and Hyperfilm were from Amersham Pharmacia Biotech (Uppsala, Sweden). GTK antiserum was made according to (22), the anti-phospho p44/p42 Thr202/Tyr204 MAPK (ERK1/2), anti-phospho (Ser473) Akt, anti-phospho Thr183/Tyr185 JNK, anti-phospho Thr180/Tyr182 p38, anti-p38, antiJNK, and anti-Akt antibody were from New England Biolabs (Beverly, MA, USA), the anti-p44/p42 MAPK (ERK1/2) and iNOS antibody were from Santa Cruz (Santa Cruz, CA, USA). The anti-PYK2 antibody was from Transduction Laboratories (Lexington, KY, USA).
Construction of Transgene

The 0.41-kb rat insulin I promoter was excised by BamHI and HindIII and inserted into a BamHI/HindIII cleaved pcDNA 3.1(-)/Myc-His B vector followed by excision of the T7 and CMV promoter by BamHI and BglII cleavage. After ligation, the vector was cleaved with XbaI and a $1.6 \mathrm{~kb}$ GTK construct, with tyr-504 mutated to phenylalanine [excised from a pcDNA3.1 (-)/Myc-His B-Vector (22) by XbaI cleavage] was inserted. The plasmid sequence was subsequently excised with SspI and DraIII and the final DNA fragment contained the rat insulin I promoter, the GTK-Y504F cDNA with a myc-epitope, and a BGH polyadenylation signal. The transgene was microinjected into fertilized CBA mouse oocytes and implanted in pseudopregnant CBA mice of a local stock at Umeå University (Umeå, Sweden). Incorporation of the transgene into the genome of the offspring was verified by PCR and Southern blot analysis on DNA obtained from tail samples from 3-week-old mice using a 5'-primer matching nucleotide 1502-1522 of the GTK cDNA (5'-GGTAGACATGGCGGCCACAGGT-3') and a 3'primer corresponding to the last 18 nucleotides of the myc-epitope (5'-TGAGATGAGTTTTTGTTC-3'). One female mouse with insertion of the transgene was obtained and bred with a control CBA mouse and when male GTK-transgenic were born they were bred with GTK-transgenic female mice. The mice used were mainly heterozygous (at least $75 \%$ ), but due to practical reasons and because there were no obvious differences in phenotype or GTK expression between homozygous and heterozygous mice we have not excluded animals being homozygous for the transgene. Transcription from the transgene was studied by RT-PCR on DNase-treated RNA from islets isolated from 3-month-old mice using the same primers as above. All animal experimentation was approved by the Institutional Review Board for Animal Experimentation.

\section{Islet Isolation and Culture}

Islets were isolated from control CBA or GTK transgenic 3- to 4-month-old mice of both genders by a collagenase digestion procedure (23) and cultured for $24 \mathrm{hr}$ in RPMI $1640+10 \%$ FCS followed by incubation in the absence or presence of cytokines $(50 \mathrm{U} / \mathrm{ml}$ of human IL- $1 \beta+1000 \mathrm{U} / \mathrm{ml}$ of murine INF- $\gamma$ ) for the indicated time points. These concentrations of cytokines were selected based on previous studies using pancreatic islets (24). The islets were then used for determination of insulin secretion, insulin content, DNA content, apoptosis, or protein expression.

\section{Insulin Release}

Ten islets in triplets were transferred to multi-well plates containing $100 \mu \mathrm{l}$ of $\mathrm{KRBH}$ buffer (114.3 $\mathrm{mM}$ of $\mathrm{NaCl}, 4.74 \mathrm{mM}$ of $\mathrm{KCl}, 1.15 \mathrm{mM}$ of $\mathrm{KH}_{2} \mathrm{PO}_{4}$, 
$1.18 \mathrm{mM}$ of $\mathrm{MgSO}_{4}, 25 \mathrm{mM}$ of $\mathrm{NaHCO}_{3}, 10.0 \mathrm{mM}$ of HEPES, $4.26 \mathrm{mM}$ of $\mathrm{NaOH}$, and 2.54 of $\mathrm{mM} \mathrm{CaCl}$; pH 7.4) supplemented with $2 \mathrm{mg} / \mathrm{ml}$ of BSA and 1.7 $\mathrm{mM}$ of glucose and incubated for $60 \mathrm{~min}$ followed by an incubation for $60 \mathrm{~min}$ in $16.7 \mathrm{mM}$ of glucose and the insulin secretion was determined. The islets were then pooled, homogenized in $200 \mu$ l of water, and used for analyzing DNA content and insulin content. Insulin was measured by radioimmunoassay (RIA) (25).

\section{Labeling Index and b-Cell Area}

Three-month-old mice were injected intraperitoneally with $1 \mathrm{mCi}$ of $\left[\right.$ methyl ${ }^{3} \mathrm{H}$ ] thymidine $/ \mathrm{kg}$ body weight $1.5 \mathrm{hr}$ before the mice were killed. The pancreas was dissected, fixed in $10 \%$ formalin, and sectioned. The labeling index was determined by $\left[{ }^{3} \mathrm{H}\right]$ thymidine autoradiography (26) and the percentage of insulin-positive area relative to the total pancreas area was determined by staining sections for insulin using an unlabeled peroxidase-antiperoxidase technique (27). The insulin-positive area was determined by two blinded independent observers on three cross-sections from different regions (caput, corpus, and cauda) of each pancreas, using a computerized image analysis system for morphometry (MOP; Videoplan, Kontron Bildanalyse Munich, Germany). To assess if there was any difference in islet cell size, a grid was placed over the insulinstained sections and the number of insulin-positive cells was divided by the insulin-positive area (number of squares).

\section{Glucose Homeostasis}

For glucose homeostasis, a glucose tolerance test was performed as follows. Male and female GTK transgenic and control CBA mice 3-4 months of age were injected intravenously with $250 \mu \mathrm{l}$ of $30 \%$ glucose, and blood glucose was determined (MediSense Pen Sensor; MediSense, Waltham, MA, USA) on blood samples collected from the tail immediately before the glucose injections and after 10, 30, 60 , and $120 \mathrm{~min}$.

\section{Cell Death and Western Blotting}

Islets were cultured for the indicated time points with or without the presence of cytokines. For cell death, islets were incubated in phosphate-buffered saline (PBS) containing $10 \mu \mathrm{g} / \mathrm{ml}$ of propidium iodide (PI) and $20 \mu \mathrm{g} / \mathrm{ml}$ of bisbenzamide (Hoechst 33342 stain) for $5 \mathrm{~min}$ at $37^{\circ} \mathrm{C}$, washed in PBS and examined with fluorescence microscopy. The percentage of apoptotic-like and necrotic-like cells was determined by differential counting of PI-positive cells by a blinded independent observer. Necroticlike and apoptotic-like cells were discriminated by the uptake of PI, appearance of cell nucleus, and size (28). For protein levels, 60 islets from each group were washed with cold PBS, briefly sonicated in SDS sample buffer (containing $\beta$-mercaptoethanol and $2 \mathrm{mM}$ of PMSF), and subjected to Western blot analysis. The membranes were incubated with the indicated antibodies and the immunoreactivity was subsequently detected by ECL.

\section{Nitrite Production}

Medium from islets cultured for $24 \mathrm{hr}$ in the presence or absence of cytokines was collected and nitrite formation was assessed as follows: $100 \mu \mathrm{l}$ of medium was added to a mixture of $0.5 \%$ naphtylenediamine dihydrochloride, $5 \%$ sulfanilamide, and $25 \% \mathrm{H}_{3} \mathrm{PO}_{4}$, and incubated for $5 \mathrm{~min}$ at room temperature. The absorbance was measured spectrophotometrically at $546 \mathrm{~nm}$ against a standard curve of sodium nitrite (29).

\section{Statistical Analysis}

The means \pm SEM for the number of observations are given. Each observation is based on the value obtained from one animal or individual islet isolation. A blinded independent observer made the cell countings (labeling index and apoptosis) and the MOP analysis ( $\beta$-cell area). Unpaired Student's $t$ test or, when appropriate, analysis of variance (ANOVA) followed by a multiple pairwise comparison procedure using the Student-Newman-Keuls method was used to determine the statistical differences between groups.

\section{Results \\ Expression of the Transgene}

Expression of the transgene was verified by PCR of the transgenic islet cDNA using a 3'primer matching the C-terminal myc-epitope. We could show that the GTK-Y504F mRNA is present in the transgenic mice only (Fig. 1A). To control that the obtained PCR product was amplified cDNA with no contamination of genomic DNA, samples that had not been treated with reverse transcriptase were run in parallel. Islets isolated from GTK-transgenic mice expressed only moderately elevated levels of the 57-kDa GTK protein (Fig. 1B) as determined by Western blot analysis of islet lysates or GTK immunoprecipitates using an unpurified GTK-reactive antibody (22).

\section{Pancreas Size, $\beta$-Cell Area, and Labeling Index}

The total pancreas of the GTK-transgenic mice was significantly larger and weighed in average almost $50 \mathrm{mg}$ more. This was not solely due to an increase in body weight of the transgenic mice because the pancreas mass relative to the mouse body weight was significantly increased in the transgenic animals (Fig. 2A). When the mouse weight was plotted against the pancreas weight (Fig. 2A), the seven animals with the lowest pancreas weight were all confined to the CBA control group. The insulin-positive area relative the total pancreas area was also increased by at least $50 \%$ in the GTK transgenic (Fig. 2B). It might be argued that an increased $\beta$-cell area 


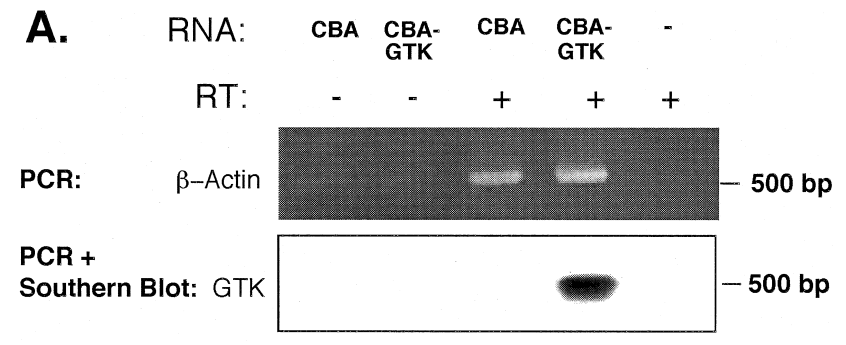

B.

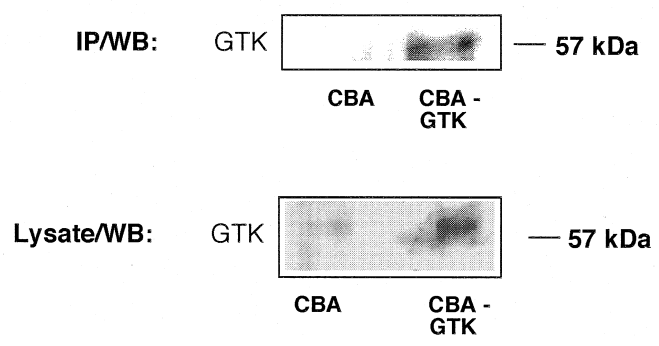

Fig. 1. GTK-expression in transgenic islets. (A) Transcription from the transgene was studied by RT-PCR and Southern blotting on equal amounts of DNase treated RNA from 3month-old mice using a $5^{\prime}$-primer matching nucleotide 15021522 of the GTK cDNA and a 3'-primer corresponding to the last 18 nucleotides of the myc-epitope. Samples not treated with reverse transcriptase (RT) were run in parallel. As control RTPCR for $\beta$-actin was performed (top). One experiment was performed. (B) Isolated islets were cultured as above, immunoprecipitated with anti-GTK antibody, and subjected to Western blot analysis for GTK (top) or lysed in SDS sample buffer supplemented with protease inhibitor, and subjected to Western blot analysis for GTK (bottom). The result is based on four independent experiments.

is a consequence of hypertrophy of the islet cells; therefore, the number of insulin-producing cells divided by the corresponding islet area was counted. The obtained results, however, indicated that the observed increased $\beta$-cell area is a consequence of $\beta$ cell number rather than the $\beta$-cell size (results not shown). The increased $\beta$-cell mass in the GTKtransgenic mice is not due to an increased $\beta$-cell replication in the adult mice because the labeling index in vivo of the 3-month-old GTK transgenic was similar to that of control mice (Fig. 2B).

\section{Insulin Content and Glucose-Stimulated Insulin Release}

The relative stimulation of insulin release, measured as the release at high glucose $(16.7 \mathrm{mM})$ divided by the release at low glucose $(1.7 \mathrm{mM})$, was increased in the isolated GTK-transgenic islets compared with the corresponding control islets (Fig. 3A). The insulin release was more impaired by cytokine treatment (IL- $1 \beta$ and INF- $\gamma$ ) in the transgenic islets than it was in the control islets. Thus, the relative stimulation of insulin release was significantly decreased when the transgenic islets had been cultured with cytokines for $24 \mathrm{hr}$ compared with the transgenic islets that had been cultured in the absence of
A.

\begin{tabular}{|c|c|c|c|}
\hline & $\begin{array}{l}\text { Body woight } \\
\text { (95) }\end{array}$ & $\begin{array}{l}\text { Panereas Weight } \\
\text { (pnil) }\end{array}$ & $\begin{array}{l}\text { Paneroas Weigeto } \\
\text { Body Weighe } \\
\text { ompai }\end{array}$ \\
\hline con-ecentrel & $39 \neq 1$ & $211 \leq 7$ & $6.5=0.3$ \\
\hline CBA-GTK & $35 \neq 1$ & $250 \times 11$ & $7.5 \pm 0.3^{\circ}$ \\
\hline
\end{tabular}

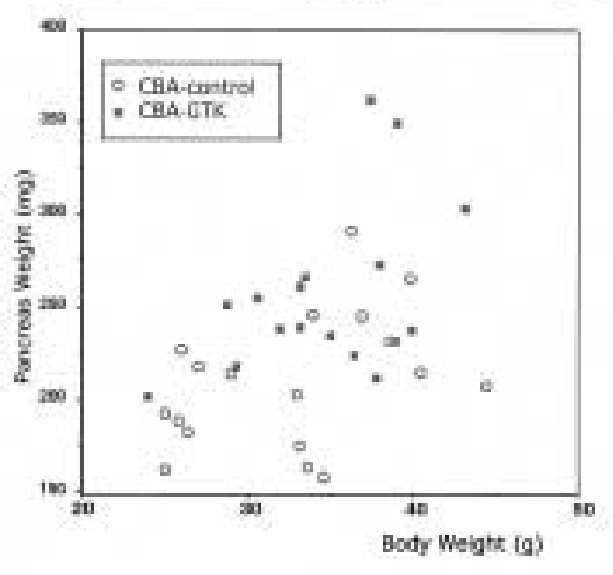

B.

\begin{tabular}{|c|c|c|}
\hline & $\begin{array}{l}\text { P-ent Aras } \\
{[\%]}\end{array}$ & $\begin{array}{l}\text { Lebeling Index } \\
\text { [N] }\end{array}$ \\
\hline caA-eontrel & $1.2+02$ & $0.19 \pm 0.06$ \\
\hline CDA-GTK & $21+03$ & $0.22=0.06$ \\
\hline
\end{tabular}

Fig. 2. $\beta$-cell mass and labeling index in GTK-transgenic and CBA control mice. (A) Male and female 3- to 5-month old mice were weighed before the pancreas was dissected and used for various experiments and the pancreas weight $(\mathrm{mg})$ per gram body weight was calculated (top). Values are mean \pm SEM from 16-18 mice. ${ }^{*} p<0.05$ and ${ }^{* *} p<0.01$ when compared with corresponding value of CBA control. The pancreas weight was plotted against body weight for each individual animal (bottom). (B) $\beta$-Cell area is the percentage of insulin-positive area relative to that of total pancreas area determined at 3 months of age for CBA control or GTK-transgenic mice. The labeling index values are the percent insulin-positive cells with nuclei that have incorporated $\left[{ }^{3} \mathrm{H}\right]$-thymidine. Values are mean \pm SEM for five observations. ${ }^{*} p<0.05$ when compared with corresponding value of CBA control.

cytokines (Fig. 3A). There was no difference in the islet insulin content per microgram DNA or insulin mRNA levels relative total mRNA, determined by RIA and Northern blotting for insulin and $\beta$-actin, respectively, between the groups (Table 1 ).

\section{Glucose Homeostasis}

To assess insulin release in vivo, glucose tolerance tests on male and female 3-month-old mice were performed. The basal blood glucose and the glucose disappearance rate after an intravenous injection of glucose were similar (Fig. 4). The blood glucose was increased to above $20 \mathrm{mM}$ at $10 \mathrm{~min}$ after the injection in both groups and diminished rapidly, returning to near basal levels after $60 \mathrm{~min}$. 
A
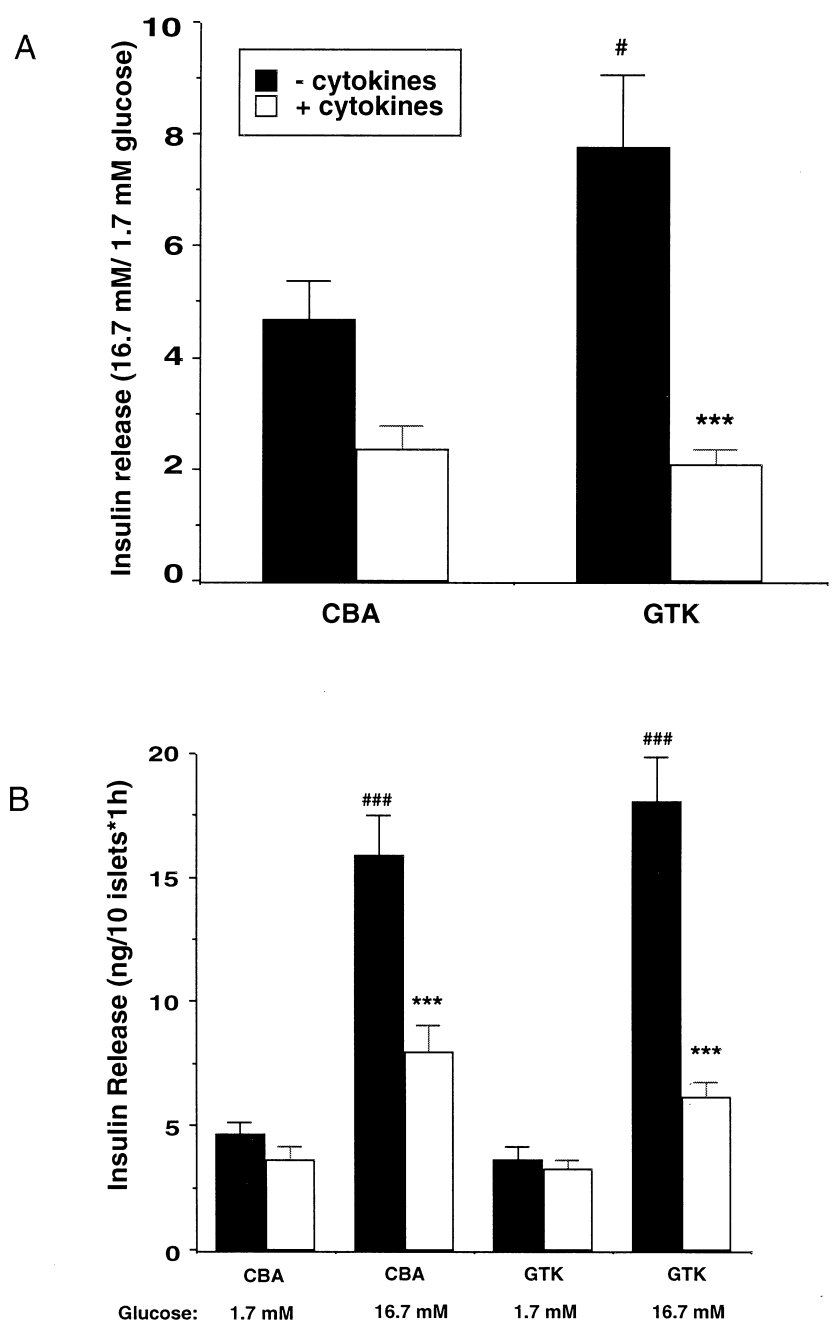

Fig. 3. Insulin secretion of islets isolated from control mice GTK-transgenic mice. Isolated islets (10 islets in triplicate) were incubated for $18 \mathrm{hr}$ with or without $50 \mathrm{U} / \mathrm{ml}$ of IL$1 \beta+1000 \mathrm{U} / \mathrm{ml}$ of IFN- $\gamma$. The islets were then incubated for $60 \mathrm{~min}$ in $1.7 \mathrm{mM}$ of glucose, followed by $60 \mathrm{~min}$ in $16.7 \mathrm{mM}$ of glucose and insulin secretion was determined. (A) The relative stimulation of insulin release calculated as the release at 16.7 of $\mathrm{mM}$ glucose divided by the release at 1.7 of $\mathrm{mM}$. (B) Insulin release at $1.7 \mathrm{mM}$ and $16.7 \mathrm{mM}$ of glucose. Bars are mean \pm SEM from 12 to 17 observations. $* * * p<0.001$ when compared with corresponding value in the absence of cytokines, $\# p<0.05$ when compared with corresponding value of the CBA control and \#\#\#p<0.001 when compared with corresponding value in $1.7 \mathrm{mM}$ glucose

\section{Cell Death and NO Production in Response to Cytokines}

Because we have previously reported increased cytokine-induced cytotoxicity of insulinoma RINm5F cells (20) overexpressing GTK-Y504F, it was of interest to study cell death in response to cytokines in the GTK-transgenic islets and compare it with that of control islets. Dissociation of islets cells may influence function and viability; therefore, whole islets were exposed to cytokines for $30 \mathrm{hr}$, stained with propidium iodide and bisbenzamide, and examined in the fluorescence microscope as described previously (28). Islets from GTK-transgenic islets exhibited a significantly reduced viability, predominantly due to an increase in apoptosis-like cell death, in response to cytokines $(50 \mathrm{U} / \mathrm{ml}$ of IL- $1 \beta+$ $1000 \mathrm{U} / \mathrm{ml}$ of INF- $\gamma$ ) compared with the control CBA islets (Fig. 5A). To see if the increased cytotoxicity was due to an induced production of NO, we measured the nitrite levels in the incubation medium as well as the expression of iNOS in response to cytokines. Cytokine treatment significantly increased NO formation to a similar degree in both groups (Fig. 5B). The expression of iNOS was also increased in islets treated with cytokines after 6 and $24 \mathrm{hr}$ of exposure to cytokines, but there was no difference between transgenic and control islets (results not shown).

Cytokine-Induced Phosphorylation of $p 38$, ERK1/2, $J N K$, and $A k t$

It has recently been shown that IL- $1 \beta$ induces phosphorylation and activation of the MAP kinases $\mathrm{p} 38$, ERK 1/2, and JNK in insulin-producing cells (12-14, 30); therefore, the phosphorylation of these kinases was assessed after stimulation of isolated islets with cytokines for different time points. The relative ERK $1 / 2$ phosphorylation, measured as the amount of phosphorylated ERK1/2 relative to the total amount of ERK1/2 in the absence of cytokines was 2-fold higher in the GTK-transgenic islets compared with the control islets. Cytokine treatment for $1.5 \mathrm{hr}$ doubled the phosphorylation of ERK1/2 in both groups, thus making the amount of phosphorylated ERK 1/2 in response to cytokine treatment higher in the transgenic islets (Fig. 6A). At 6 and $24 \mathrm{hr}$ with cytokines, the phosphorylation of ERK1/2 returned to basal levels in both groups.

The relative phosphorylation of $\mathrm{p} 38$ in the absence of cytokines was $50 \%$ lower in the GTKtransgenic islets. Cytokine treatment for $1.5 \mathrm{hr}$, however, increased the phosphorylation of p38 to nearly the same levels in both groups. Thus, cytokine treatment increased p38 phosphorylation three times in the control islets and six times in the GTK-transgenic islets. After a 6-hr stimulation, the p38 phosphorylation in the control cells returned to near basal levels, whereas the phosphorylation in the GTK cells was still three times higher than the basal level (Fig. 6B).

The relative JNK phosphorylation was similar in the GTK islets and control islets. Both groups had a low basal phosphorylation of JNK that increased 5 -fold in response to a 1.5 -hr stimulation, decreased to a 3-fold increase at $6 \mathrm{hr}$ and returned to basal levels at $24 \mathrm{hr}$ with cytokines (Fig. 6C).

Because Il- $1 \beta$ has been shown to activate and phosphorylate Akt in other cell types (15-17), we decided to investigate the phosphorylation in response to IL- $1 \beta$ and INF- $\gamma$ in islets from control CBA mice and GTK-transgenic mice. We found that the relative phosphorylation of Akt is increased to the same extent in the control and GTK-transgenic islets 
Table 1. Insulin and DNA content of isolated islets from GTK-transgenic and CBA control mice

\begin{tabular}{lcccc}
\hline & $\begin{array}{c}\text { IL-1 } \beta / \\
\text { INF- } \gamma\end{array}$ & $\begin{array}{c}\text { DNA Content } \\
(\mu \text { g/30 islets })\end{array}$ & $\begin{array}{c}\text { Insulin Content } \\
(\mu \mathrm{g} / \mu \mathrm{g} \text { DNA })\end{array}$ & $\begin{array}{c}\text { Insulin mRNA } \\
\text { Relative Levels }\end{array}$ \\
\hline CBA control & - & $0.72 \pm 0.04$ & $900 \pm 120$ & $1.9 \pm 0.4$ \\
CBA control & + & $0.64 \pm 0.08$ & $1070 \pm 200$ & n.d. \\
CBA-GTK & - & $0.64 \pm 0.08$ & $1020 \pm 125$ & $1.8 \pm 0.3$ \\
CBA-GTK & + & $0.60 \pm 0.08$ & $1070 \pm 100$ & n.d.
\end{tabular}

Ten islets in triplets were isolated from control or GTK-transgenic CBA mice of both genders, cultured in RPMI $1640+10 \%$ serum for $24 \mathrm{hr}$ in the absence or presence of $1000 \mathrm{U} / \mathrm{ml} \mathrm{INF}-\gamma$ and $50 \mathrm{U} / \mathrm{ml} \mathrm{IL}-1 \beta$ and used for insulin release (see Fig. 2). The islets were then pooled, homogenized in $200 \mu \mathrm{l}$ of water and the insulin and DNA contents were measured. Values are mean \pm SEM for 12 observations. Equal amounts of total RNA from 60 islets cultured for $24 \mathrm{hr}$ in RPMI $1640+10 \%$ serum were run on a denaturing agarose gel and subjected to Northern blotting for insulin and $\beta$-actin. The relative insulin mRNA levels were determined by densitometry. Values are mean \pm SEM for 10 observations; n.d., not determined.

after a 6-hr incubation and that the phosphorylation returned to basal levels again after $24 \mathrm{hr}$ culture with cytokines (Fig. 6D).

Proline-rich tyrosine kinase 2 (PYK2, also named RAFTK/CAK $\beta /$ CADTK) and focal adhesion kinase (FAK) are structurally related protein tyrosine kinases. FAK is known to generate cell survival signals, whereas PYK2 has been shown to both induce and protect against cell death (reviewed in Schlaepfer et al. [31]). To study PYK2 and FAK levels in response to cytokines in islets, we examined the expression in isolated islets cultured for $24 \mathrm{hr}$ in the absence and presence of cytokines. The PYK2 levels were significantly elevated in the control

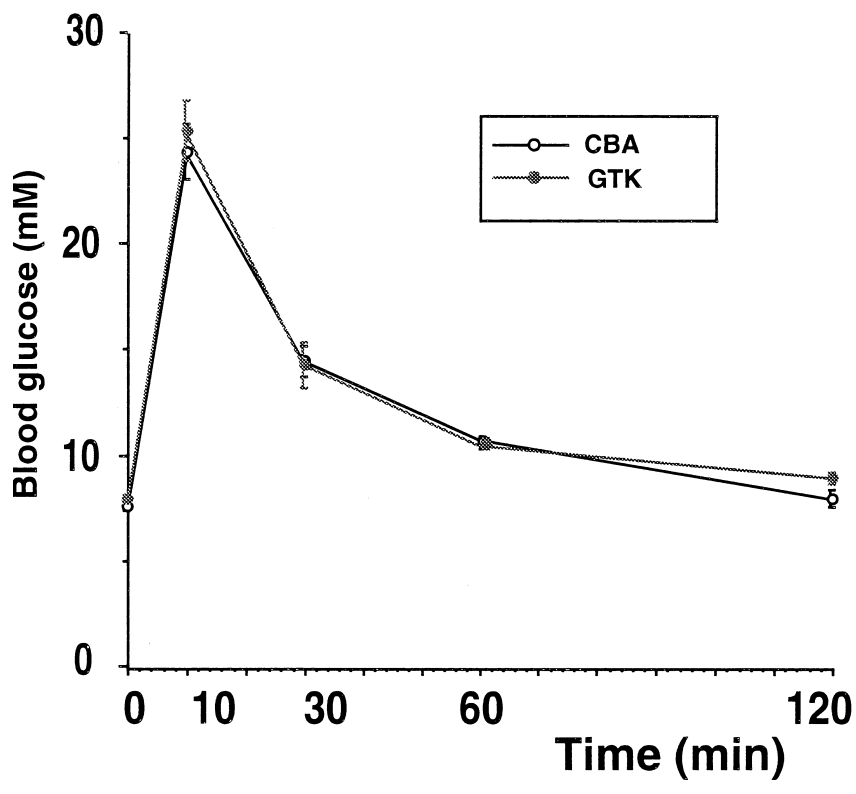

Fig. 4. Blood glucose profiles after an intravenous injection of glucose. (A) Male and female 3-month-old mice were given an intravenous injection of $250 \mu \mathrm{l}$ of glucose $(30 \%)$ and the plasma glucose levels were measured at the indicated time points. Data are mean \pm SEM from 13 mice. islets treated with cytokines. The GTK-transgenic islets contained lower PYK2 levels in the basal state compared to the control, and the expression was not significantly affected by the cytokine treatment; thus, the transgenic islets contained about half the amount of PYK2 in the presence of cytokines compared with the control islets (Fig. 7B). We could not observe any significant changes in the FAK levels in response to cytokines, nor did we see any differences between the two groups (Fig. 7A).

\section{Discussion}

Protein tyrosine kinases play an important role in the regulation of numerous pathways, leading to disperse effects such as replication, migration, or cell death. We have previously shown that GTK, a cytoplasmic tyrosine kinase, is involved in signal transduction pathways controlling multiple responses including growth, differentiation, and survival (20-22). GTK is endogenously expressed in fetal and adult islets of Langerhans (19), but its function in these cells remains to be determined. To assess a role of GTK for $\beta$ cells, a transgenic mouse expressing Y504F-mutated GTK under the control of the rat insulin promoter was generated. Islets isolated from GTK-transgenic mice expressed moderately elevated levels of GTK protein, but because the transgene is a mutant form of GTK that has increased kinase activity compared with the endogenously expressed wildtype GTK, the effects observed in the transgenic animals are likely due to the increased GTK activity rather than nonspecific overexpression of a protein.

In the present study, we have shown that the relative $\beta$-cell area and the total pancreas mass were increased in the GTK-transgenic mice compared with control mice. Because there was no difference in $\beta$-cell labeling index in the 3-month-old animals, the larger $\beta$-cell mass in the GTK-transgenic pancreas could not be explained by an increased replication of the $\beta$ cells at this age. Other explanations for the increased $\beta$-cell mass could either be that 

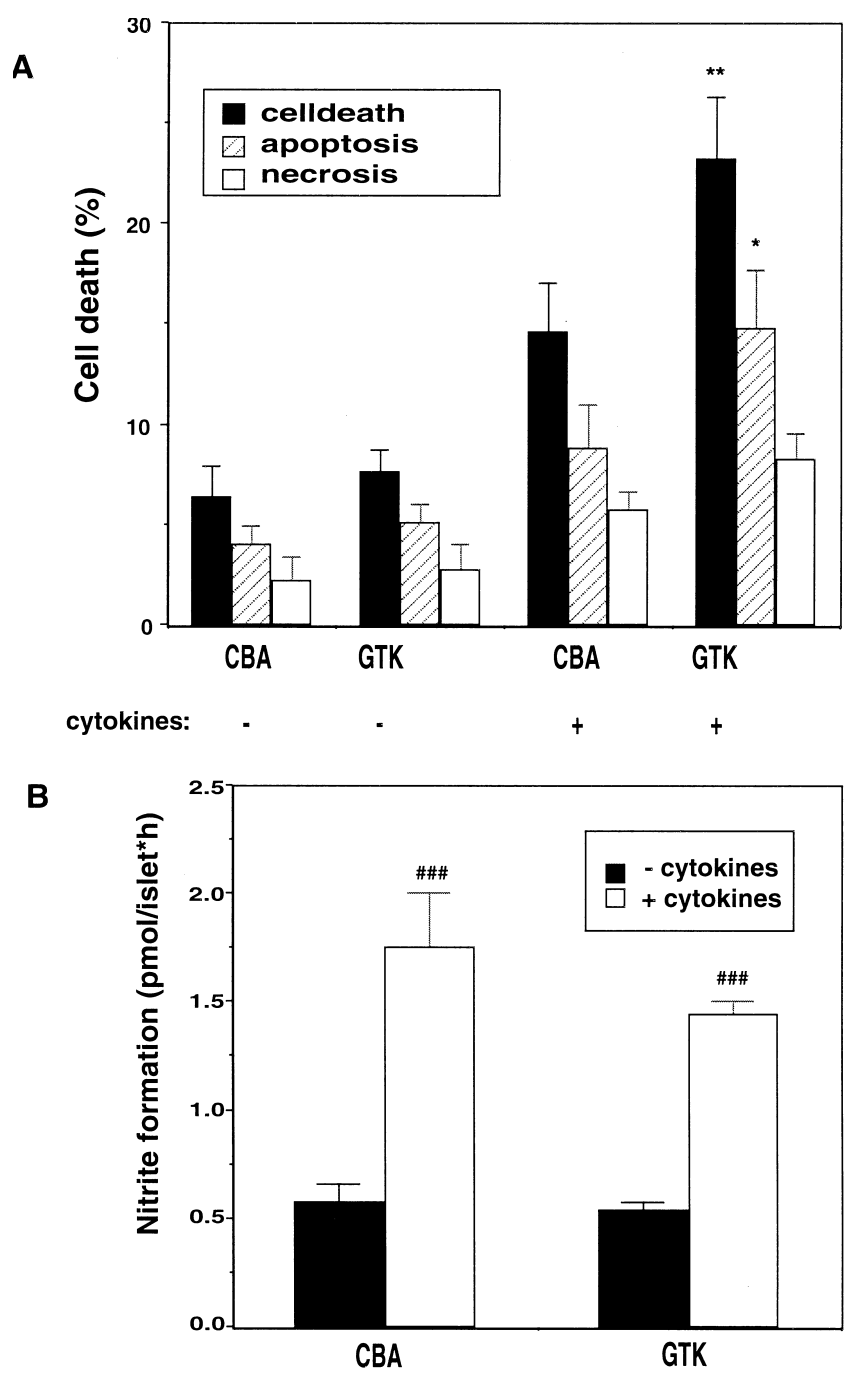

Fig. 5. Cell viability in response to cytokines. (A) Isolated islets were cultured for $30 \mathrm{hr}$ in the absence or presence of $50 \mathrm{U} / \mathrm{ml}$ of IL- $1 \beta+1000 \mathrm{U} / \mathrm{ml}$ of IFN- $\gamma$. The islets were then stained with propidium iodide and Hoechst stain; necrotic-like and apoptotic-like cells were counted. (B) Nitrite formation from 50 islets incubated for $24 \mathrm{hr}$ with or without cytokines was determined in incubation media. Bars are mean \pm SEM for nine independent experiments. ${ }^{*} p<0.05$ and ${ }^{* *} p<0.01$ when compared with corresponding value of CBA-control and \#\#\# $<$ 0.001 when compared with corresponding value in the absence of cytokines.

GTK overexpression increases $\beta$-cell replication in the neonatal pancreas, $\beta$-cell viability, or $\beta$-cell neoformation. Because the transgene is expressed in the insulin-producing $\beta$ cells only, it would not be able to induce $\beta$-cell neogenesis directly, although it is possible that a GTK-dependent change of $\beta$-cell function could influence proliferation and differentiation of other cell types, such as the ductal precursor cells in the pancreas. The significant increase in the size of the whole pancreas cannot, however, be explained solely by the increase in $\beta$-cell mass. It is presently not known how GTK could bring this about, but one possible explanation is that the GTK- dependent increase in $\beta$-cell mass results in elevated insulin secretion. Insulin is a potent growth factor known to induce proliferation through activation of mitogenic pathways such as the ERK1/2 pathway (reviewed in $[32,33]$ ). The relative insulin secretion in response to glucose in vitro was also slightly enhanced and appears to reflect both an absolute decrease in insulin release at low glucose levels and elevated secretion at high glucose.

The most obvious effect of GTK in $\beta$ cells was the markedly reduced viability of the transgenic islets when cultured in the presence of cytokines. An almost $60 \%$ increase in islet cell death was observed in the GTK-transgenic group compared with the cytokine-treated control islets, and this was mainly due to an increase in apoptosis-like cell death. These findings are in line with a previous experiment in the insulinoma RINm5F cell line overexpressing Y504F-mutated GTK, in which the cytokine-induced cell death was increased by at least $70 \%$ compared with the control cells (20). It is well documented that within the time and dose window used in this study, cytokines exert a $\beta$-cell selective toxic effect (34); therefore, we did not discriminate between $\beta$ cells and non- $\beta$ cells when studying cytokine-induced cytotoxicity. Moreover, because the transgene is exclusively expressed in insulin-producing cells, the increased cytotoxicity observed in the transgenic islets is likely to occur in the $\beta$ cells.

To study the mechanism behind the rise in cytokine-mediated death of the GTK-expressing cells, we looked at different pathways that have been suggested to play a role in mediating the cytotoxic effects of IL- $1 \beta$ and INF- $\gamma$. We did not observe any difference in NO production or iNOS expression between the two groups, indicating that GTK mediates the increase in cytokine-induced cytotoxicity by a pathway independent of iNOS. Although NO has been proven to be an important second messenger for the cytotoxic effect of IL- $1 \beta$, NO alone does not seem to be sufficient to bring about this destruction. It has, for instance, been shown that FACS-purified $\beta$ cells from iNOS-deficient mice are as susceptible to cytokine-induced apoptosis as the wild-type $\beta$ cells (8).

IL- $1 \beta$ has recently been shown to induce activation of the three MAP/SAPKs p38, ERK1/2, and JNK to a larger extent in transformed and primary $\beta$ cells (12-14) than in $\alpha$ cells, and this response was not found to be associated with a more pronounced IL-1-induced NO production. It was therefore suggested that an increased MAPK signaling in response to IL- $1 \beta$ represents a molecular marker of $\beta$ cell differentiation as well as a possible explanation for the increased susceptibility to cytokines (13). Our data demonstrate that ERK1/2, p38, and JNK are all activated by cytokines in mouse islets, and that the GTK-transgenic islets contain higher basal levels of phosphorylated ERK1/2 but lower basal levels of phosphorylated p 38 compared with control 

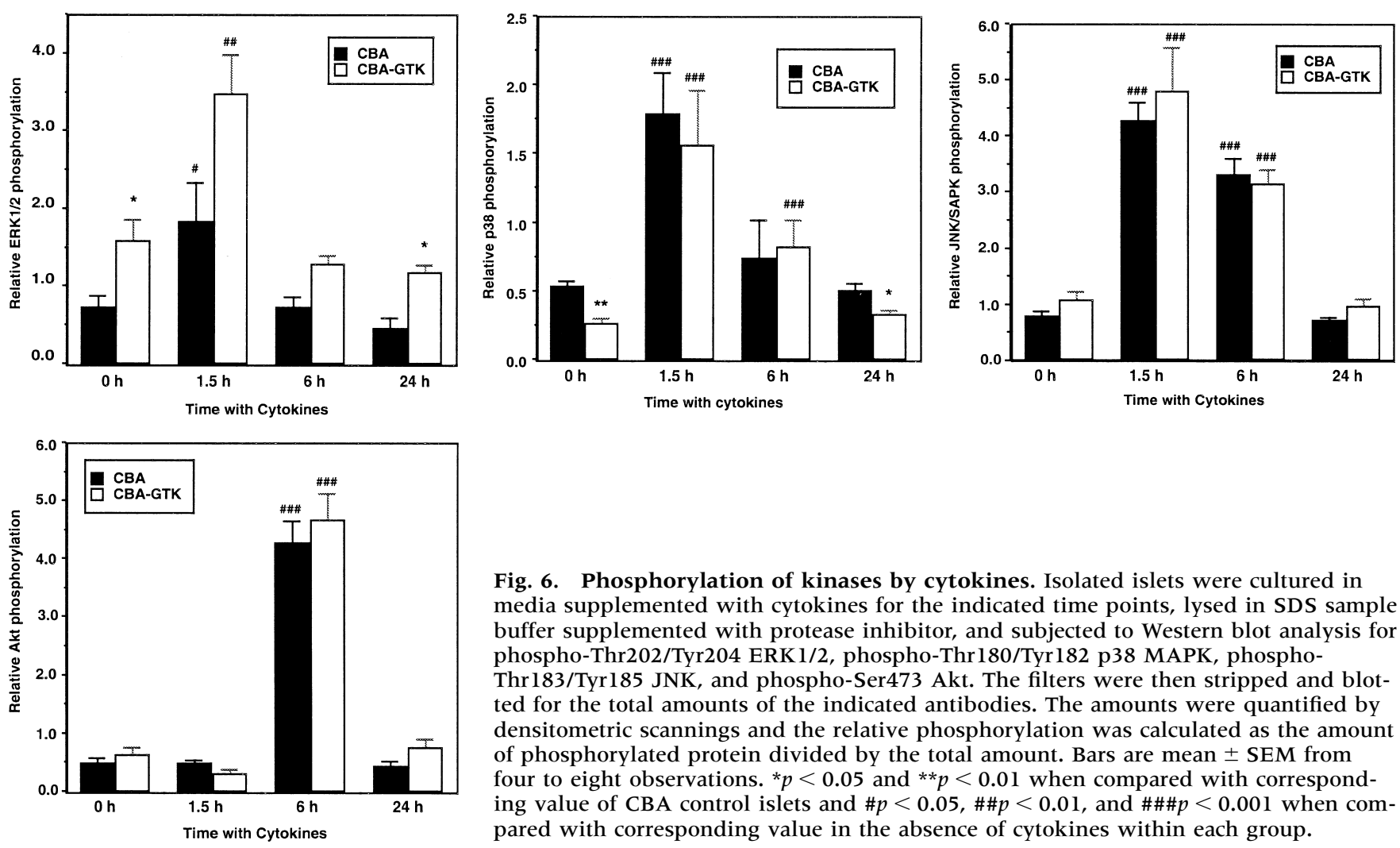

Fig. 6. Phosphorylation of kinases by cytokines. Isolated islets were cultured in media supplemented with cytokines for the indicated time points, lysed in SDS sample buffer supplemented with protease inhibitor, and subjected to Western blot analysis for phospho-Thr202/Tyr204 ERK1/2, phospho-Thr180/Tyr182 p38 MAPK, phospho-

Thr183/Tyr185 JNK, and phospho-Ser473 Akt. The filters were then stripped and blotted for the total amounts of the indicated antibodies. The amounts were quantified by densitometric scannings and the relative phosphorylation was calculated as the amount of phosphorylated protein divided by the total amount. Bars are mean \pm SEM from four to eight observations. ${ }^{*} p<0.05$ and ${ }^{* *} p<0.01$ when compared with correspond-

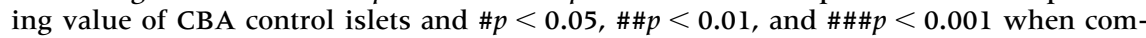
pared with corresponding value in the absence of cytokines within each group.

islets. The total amount of phosphorylated MAP kinases was thus similar in the two groups in the absence of cytokines; the lower levels of p38 is compensated for by the elevated levels of ERK1/2. However, when the islets are stimulated with cytokines, the total amount of activated MAPKs is higher in the transgenic islets compared to the control islets owing to the increased levels of phosphoERK1/2 in combination with equal levels of phosphorylated p38 and JNK. Could the increased MAPK activation observed in the GTK-transgenic islets be responsible for their increased sensitivity to cytokines? It is generally believed that activation of JNK and p38 MAP kinases is associated with promotion of apoptosis (reviewed in Cross et al. [35]) and specific JNK inhibitors have been shown to protect against IL- $1 \beta$-induced apoptosis (13). However, the role of ERK1/2 in cytokine-induced cell death is more controversial, because ERK1/2 has been suggested to contribute to IL- $1 \beta$-induced apoptosis in $\beta$ cells (14) and NO-mediated cell death in macrophages (36), although ERK1/2 is generally believed to promote survival $(37,38)$. To make this issue increasingly complicated, it has been shown that specific p38 and ERK1/2 inhibitors protect cells from IL- $1 \beta$-induced NO production $(12,14)$; however, this protection was less marked when the inhibitors were used together with a combination of IL- $1 \beta$ and INF- $\gamma$. Nevertheless, an overall induction of MAP kinase activation might be important for the increased sensitivity of the GTK-transgenic islets to the cytotoxic action of IL- $1 \beta$ and INF- $\gamma$, although other signaling pathways might be involved as well.

In this study, we also show for the first time that Akt is phosphorylated in response to cytokine treatment in pancreatic islet cells. It has previously been shown that IL-1 treatment reduces apoptosis caused by growth factor or serum withdrawal by activating the phosphatidyl inositol 3-kinase/Akt pathway in endothelial cells and astrocytes (15-18), and it has been suggested that this involves the activation of the transcription factor $\mathrm{NF} \kappa \mathrm{B}(15,17,18)$. The PI3kinase/Akt pathway is most likely not involved in the altered viability of the GTK-expressing islets, however, because the activation of Akt caused by cytokines was equal in the two groups.

In the present study, we also show that the PYK2 levels increase in the control islets but not GTK-transgenic islets, following a 24-hr culture with cytokines. PYK2 has never before been studied in insulin-producing cells, but a recent study demonstrated that PYK2 participates in the antiviral response by INF- $\gamma$ in fibroblast by activating the Jak2/Stat 1 pathway (39). PYK2 is structurally related to FAK, which is generally believed to be involved in integrin signaling and survival (reviewed in Schlaepfer et al. [31]). Although PYK2 and FAK share many downstream effectors, accumulating reports are showing that PYK2 mediates signals via pathways distinct from those of FAK. It has, for ex- 
A.

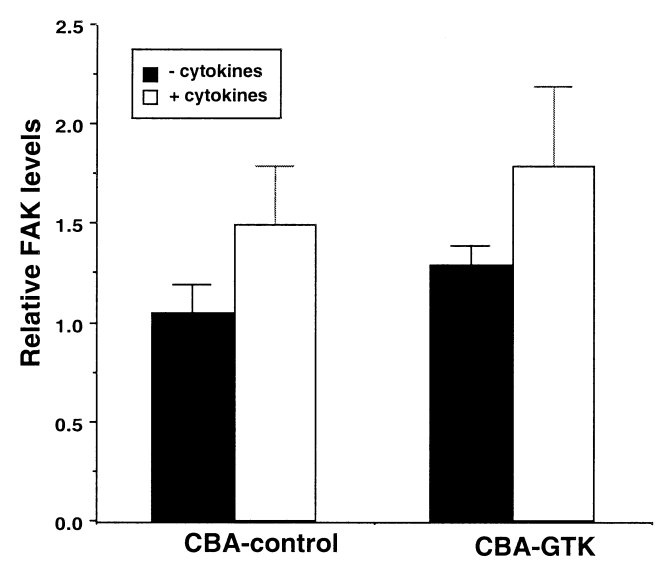

B.

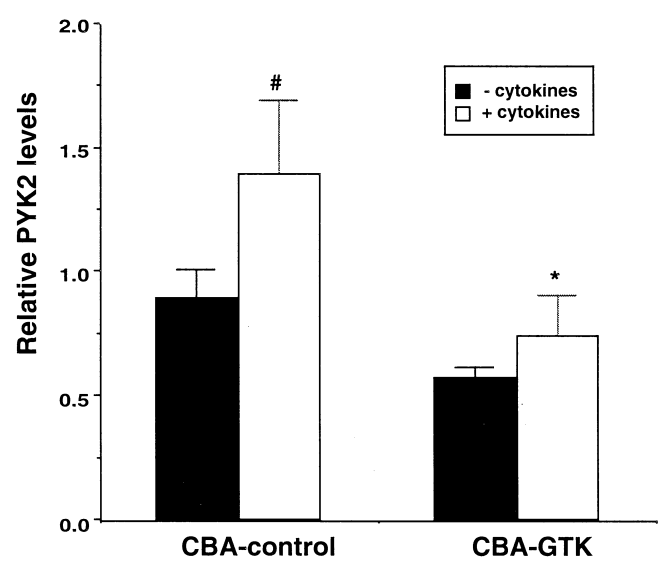

Fig. 7. FAK and PYK2 levels in islets isolated from control and GTK-transgenic mice. Isolated islets were cultured as above, lysed in SDS sample buffer supplemented with protease inhibitor, and subjected to Western blot analysis for the indicated proteins. Bars are mean \pm SEM from five to nine observations. * $p<0.05$ when compared with corresponding value of CBA-control islets and \#p<0.05 when compared with corresponding value in the absence of cytokines within each group.

ample, been shown that overexpression of PYK2, but not FAK, in rat and mouse fibroblasts leads to apoptotic cell death (40). Different studies have thus shown both pro-apoptotic as well as survival effects of PYK2-signaling, and therefore it is not yet possible to say what role PYK2 plays for cytokinemediated cytotoxicity in $\beta$ cells. The decreased PYK2 expression in the GTK-transgenic islets might be a compensatory effect in attempts to decrease the enhanced MAPK signaling in these cells because PYK2 has been shown to induce activation of MAP kinases in different cell systems (41-43). If instead PYK2 is involved in promoting $\beta$-cell survival, up-regulation of PYK2 might be a way for $\beta$ cells to protect themselves from the cytotoxic effects of cytokines and the inability of the transgenic islets to do so might then induce their cytokine sensitivity.

We recently found that GTK expression in PC12 cells induces neurite outgrowth, which was accom- panied with increased phosphorylation of the adaptor protein Shb and activation of the Rapl pathway (21). Overexpression of Shb in PC12 cells has also been found to induce NGF-dependent neurite outgrowth as well as Rapl activation $(44,45)$, indicating that GTK signals to promote neurite outgrowth via Shb. Interestingly, transgenic mice expressing Shb under the control of the rat insulin promoter exhibit a phenotype very similar to the one observed in the GTK-transgenic mice (24). Thus, the Shbtransgene mice display an increased relative $\beta$-cell area, an enhanced stimulation of insulin release of isolated islets and a decreased islet cell viability in response to cytokines compared with the corresponding control. These observed similarities in combination with the results obtained in the PC12 cells suggest that GTK could signal via Shb to induce part of its effects in the GTK-transgenic mice.

In conclusion, the results presented in this study suggest that GTK has dual effects in the $\beta$ cells; whereas GTK induces the $\beta$-cell mass by unknown mechanisms, it could also enhance islet cell death in response to cytokines and may thus contribute to the $\beta$-cell damage in type 1 diabetes.

\section{Acknowledgments}

We are grateful to Drs Helena Edlund and Ulf Ahlgren for help with generating the transgenic mice and to Ing-Britt Hallgren and Ing-Marie Mörsare for technical assistance. This work was supported by grants from the Juvenile Diabetes Foundation International, the Swedish Medical Research Council (31X-10822), the Swedish Diabetes Association, the Novo-Nordisk Foundation, and the Family Ernfors Fund.

\section{References}

1. Mauricio D, Mandrup-Poulsen T. (1998) Apoptosis and the pathogenesis of IDDM: a question of life and death. Diabetes 47: 1537-1543.

2. Rabinovitch A, Suarez-Pinzon WL, Shi Y, Morgan AR, Bleackley RC. (1994) DNA fragmentation is an early event in cytokine-induced islet beta-cell destruction. Diabetologia 37 : 733-738.

3. Rabinovitch A, Suarez-Pinzon WL. (1998) Cytokines and their roles in pancreatic islet beta-cell destruction and insulin-dependent diabetes mellitus. Biochem. Pharmacol. 55: 1139-1149.

4. Rabinovitch A. (1998) An update on cytokines in the pathogenesis of insulin-dependent diabetes mellitus. Diabetes Metab. Rev. 14: 129-151.

5. Finegood DT, Scaglia L, Bonner-Weir S. (1995) Dynamics of beta-cell mass in the growing rat pancreas. Estimation with a simple mathematical model. Diabetes 44: 249-256.

6. Mandrup-Poulsen T. (1996) The role of interleukin-1 in the pathogenesis of IDDM. Diabetologia 39: 1005-1029.

7. Eizirik DL, Flodström M, Karlsen AE, Welsh N. (1996) The harmony of the spheres: inducible nitric oxide synthase and related genes in pancreatic beta cells. Diabetologia 39: 875-890.

8. Liu D, Pavlovic D, Chen MC, Flodström M, Sandler S, Eizirik DL. (2000) Cytokines induce apoptosis in beta-cells isolated from mice lacking the inducible isoform of nitric oxide synthase (iNOS-/-). Diabetes 49: 1116-1122. 
9. Yamada K, Takane-Gyotoku N, Yuan X, Ichikawa F, Inada C, Nonaka K. (1996) Mouse islet cell lysis mediated by interleukin-1-induced Fas. Diabetologia 39: 1306-1312.

10. Zumsteg U, Frigerio S, Holländer GA. (2000) Nitric oxide production and Fas surface expression mediate two independent pathways of cytokine-induced murine beta-cell damage. Diabetes 49: 39-47.

11. Suarez-Pinzon W, Sorensen O, Bleackley RC, Elliott JF, Rajotte RV, Rabinovitch A. (1999) Beta-cell destruction in NOD mice correlates with Fas (CD95) expression on betacells and proinflammatory cytokine expression in islets. Diabetes 48: 21-28.

12. Larsen CM, Wadt KA, Juhl LF, et al. (1998) Interleukinlbeta-induced rat pancreatic islet nitric oxide synthesis requires both the p38 and extracellular signal-regulated kinase 1/2 mitogen-activated protein kinases. J. Biol. Chem. 273: 15294-15300.

13. Ammendrup A, Maillard A, Nielsen K, et al. (2000) The cJun amino-terminal kinase pathway is preferentially activated by interleukin- 1 and controls apoptosis in differentiating pancreatic beta-cells. Diabetes 49: 1468-1476.

14. Pavlovic D, Andersen NA, Mandrup-Poulsen T, Eizirik DL. (2000) Activation of extracellular signal-regulated kinase (ERK) $1 / 2$ contributes to cytokine-induced apoptosis in purified rat pancreatic b- cells [In Process Citation]. Eur. Cytokine Netw. 11: 267-274.

15. Pousset F, Dantzer R, Kelley KW, Parnet P. (2000) Interleukin1 signaling in mouse astrocytes involves Akt: a study with interleukin-4 and IL-10. Eur. Cytokine Netw. 11: 427-434.

16. Madge LA, Pober JS. (2000) A phosphatidylinositol 3kinase/Akt pathway, activated by tumor necrosis factor or interleukin-1, inhibits apoptosis but does not activate NFkappaB in human endothelial cells. J. Biol. Chem. 275: 15458-15465.

17. Sizemore N, Leung S, Stark GR. (1999) Activation of phosphatidylinositol 3-kinase in response to interleukin- 1 leads to phosphorylation and activation of the NF-kappaB p65/RelA subunit. Mol. Cell Biol. 19: 4798-4805.

18. Reddy SA, Huang JH, Liao WS. (1997) Phosphatidylinositol 3-kinase in interleukin 1 signaling. Physical interaction with the interleukin 1 receptor and requirement in NFkappaB and AP-1 activation. J. Biol. Chem. 272: 29167-29173.

19. Öberg-Welsh C, Welsh M. (1995) Cloning of BSK, A murine FRK homologe with a specific pattern of tissue distribution. Gene 152: 239-242.

20. Annerén C, Welsh M. (2000) Role of the Bsk/Iyk nonreceptor tyrosine kinase for the control of growth and hormone production in RINm5F cells [In Process Citation]. Growth Factors 17: 233-247.

21. Annerén C, Reedquist KA, Bos JL, Welsh M. (2000) GTK, a Src-related tyrosine kinase, induces nerve growth factorindependent neurite outgrowth in PC12 cells through activation of the Rapl pathway. Relationship to Shb tyrosine phosphorylation and elevated levels of focal adhesion kinase. $J$. Biol. Chem. 275: 29153-29161.

22. Öberg-Welsh C, Annerén C, Welsh M. (1998) Mutation of C-terminal tyrosine residues Y497/Y504 of the Src-family member Bsk/Iyk decreases NIH3T3 cell proliferation. Growth Factors 16: 111-124.

23. Sandler S, Andersson A, Hellerström C. (1987) Inhibitory effects of interleukin 1 on insulin secretion, insulin biosynthesis, and oxidative metabolism of isolated rat pancreatic islets. Endocrinology 121: 1424-1431.

24. Welsh M, Christmansson L, Karlsson T, Sandler S, Welsh N. (1999) Transgenic mice expressing Shb adaptor protein under the control of rat insulin promoter exhibit altered viability of pancreatic islet cells. Mol. Med. 5: 169-180.

25. Halban PA, Wollheim CB, Blondel B, Renold AE. (1980) Long-term exposure of isolated pancreatic islets to mannoheptulose: evidence for insulin degradation in the beta cell. Biochem. Pharmacol. 29: 2625-2633.

26. Tyrberg B, Eizirik DL, Hellerström C, Pipeleers DG, Andersson A. (1996) Human pancreatic beta-cell deoxyribonucleic acid-synthesis in islet grafts decreases with increasing organ donor age but increases in response to glucose stimulation in vitro. Endocrinology 137: 5694-5699.

27. Erlandsen SL, Parsons JA, Burke JP, Redick JA, Van Orden DE, Van Orden LS. (1975) A modification of the unlabeled antibody enzyme method using heterologous antisera for the light microscopic and ultrastructural localization of insulin, glucagon and growth hormone. J. Histochem. Cytochem. 23: 666-677.

28. Saldeen J. (2000) Cytokines induce both necrosis and apoptosis via a common Bcl-2- inhibitable pathway in rat insulinproducing cells. Endocrinology 141: 2003-2010.

29. Green LC, Wagner DA, Glogowski J, Skipper PL, Wishnok JS, Tannenbaum SR. (1982) Analysis of nitrate, nitrite, and [15N]nitrate in biological fluids. Anal. Biochem. 126: 131-138.

30. Welsh N. (1996) Interleukin-1 beta-induced ceramide and diacylglycerol generation may lead to activation of the c-Jun NH2terminal kinase and the transcription factor ATF2 in the insulin-producing cell line RINm5F. J. Biol. Chem. 271: 8307-8312.

31. Schlaepfer DD, Hauck CR, Sieg DJ. (1999) Signaling through focal adhesion kinase. Prog. Biophys. Mol. Biol. 71: 435-478.

32. Avruch J. (1998) Insulin signal transduction through protein kinase cascades. Mol. Cell Biochem. 182: 31-48.

33. Combettes-Souverain M, Issad T. (1998) Molecular basis of insulin action. Diabetes Metab. 24: 477-489.

34. Mandrup-Poulsen T, Egeberg J, Nerup J, Bendtzen K, Nielsen JH, Dinarello CA. (1987) Ultrastructural studies of time-course and cellular specificity of interleukin-1 mediated islet cytotoxicity. Acta. Pathol. Microbiol. Immunol. Scand. [C] 95: $55-63$.

35. Cross TG, Scheel-Toellner D, Henriquez NV, Deacon E, Salmon M, Lord JM. (2000) Serine/threonine protein kinases and apoptosis. Exp. Cell Res. 256: 34-41.

36. Mohr S, McCormick TS, Lapetina EG. (1998) Macrophages resistant to endogenously generated nitric oxide-mediated apoptosis are hypersensitive to exogenously added nitric oxide donors: dichotomous apoptotic response independent of caspase 3 and reversal by the mitogen-activated protein kinase kinase (MEK) inhibitor PD 098059. Proc. Natl. Acad. Sci. USA 95: 5045-5050.

37. Birkenkamp KU, Dokter WH, Esselink MT, Jonk LJ, Kruijer W, Vellenga E. (1999) A dual function for p38 MAP kinase in hematopoietic cells: involvement in apoptosis and cell activation. Leukemia 13: 1037-1045.

38. Xia Z, Dickens M, Raingeaud J, Davis RJ, Greenberg ME. (1995) Opposing effects of ERK and JNK-p38 MAP kinases on apoptosis. Science 270: 1326-1331.

39. Takaoka A, Tanaka N, Mitani Y, et al. (1999) Protein tyrosine kinase Pyk2 mediates the Jak-dependent activation of MAPK and Stat 1 in IFN-gamma, but not IFN-alpha, signaling. Embo J. 18: $2480-2488$

40. Xiong W, Parsons JT. (1997) Induction of apoptosis after expression of PYK2, a tyrosine kinase structurally related to focal adhesion kinase. J. Cell Biol. 139: 529-539.

41. Murasawa S, Matsubara H, Mori Y, et al. (2000) Angiotensin II initiates tyrosine kinase Pyk2-dependent signalings leading to activation of Racl-mediated c-Jun NH2-terminal kinase. J. Biol. Chem. 275: 26856-26863.

42. Bandyopadhyay G, Sajan MP, Kanoh Y, et al. (2000) Glucose activates MAP kinase (ERK) through proline-rich tyrosine kinase-2 and the Glut 1 glucose transporter. J. Biol. Chem. 275:40817-40826.

43. Pandey P, Avraham S, Kumar S, et al. (1999) Activation of p38 mitogen-activated protein kinase by PYK2/related adhesion focal tyrosine kinase-dependent mechanism. J. Biol. Chem. 274: 10140-10144.

44. Karlsson T, Kullander K, Welsh M. (1998) The Src homology 2 domain protein Shb transmits basic fibroblast growth factorand nerve growth factor-dependent differentiation signals in PC12 cells. Cell Growth Differ. 9: 757-766.

45. Lu L, Annerén C, Reedquist CA, Bos JL, Welsh M. (2000) NGF-Dependent neurite outgrowth in PC12 cells overexpressing the Src homology 2-domain protein Shb requires activation of the Rapl pathway. Exp. Cell Res. 259: 370377. 